\title{
Wilfrid Wilson Gibson
}

\section{Willem van Doorn}

To cite this article: Willem van Doorn (1920) Wilfrid Wilson Gibson, English Studies, 2:1-6, 161-175, DOI: $10.1080 / 00138382008596404$

To link to this article: http://dx.doi.org/10.1080/00138382008596404

曲 Published online: 13 Aug 2008.

Submit your article to this journal 저

Q View related articles $₫$ 


\section{Wilfrid Wilson Gibson.}

I.

Some time ago 'the Athenæum Literary Department' started a series of booklets under the general title of 'The Westminster Classics'. They are sixpence each, and, if one may say so, rather atavistic in appearance. In fact, they are not unlike our own 'Pantheon' series, which - pace the glorious shades of Vondel, Hooft, Breero, Huygens and Staring - I cordially detested when I was a youth, and which, having come to man's estate dong ago, I still detest, for their unattractive get-up, for the prehistoric sschoolroom atmosphere they suggest or exhale, and for their greyish or Jbluish paper, against which the small and worn type looks blurred.

E. Unwilling as I am to admit any extenuating circumstances in the case of The chief benefiters by the Pantheon atrocities, - in view of the present Ginhuman dearth both of noble natures and of decent paper, 1 cannot find it an my heart to blame the management of the Athenæum for their attempt Go provide the lean of purse with something good to read on the principle rof enclosing fair Portia's likeness in a casket of unseemly lead. So may the Toutward shows be least themselves.... Also, the projected series is of an Finconventionality which rather appeals to me, as number two, for instance, consists of twenty-three poems selected from the later work of Wilfrid Wilson Gibson. Much as it may have gratified the poet to be proclaimed a classic on his lifetime, if only a Westminster classic, (though surely the Athenæum Hall-mark is not a thing to be sneered at), it must have gratified him far tmore to see a new extension of his circle of readers. Art, even 'individuzalistic' art, if such a thing exists - is not an end in itself, but a means ga an end. Having put his visions on canvas a painter does not want to stack them in a cellar, loft or alcove, of human eye unseen; he wants his opaintings to be looked at, to be admired and liked. He wants to share his visions with others, to share them with the greatest possible number. And zimilarly a poet wants an audience; failing to gather one he will, of course, Find some kind of substitute, and he may, and often will, pretend to be quite J Jatisfied with a circle of sympathizers consisting of his lady-love, his fyoungest sister, and his old aunt, with, perhaps, an occasional aesthete thrown in, - nay, he may, as Gibson did in his first period, play his harp ato imaginary kings and queens and knights, singing about imaginary kings and knights and queens.... But we may feel assured that all the time the poet is aware of the make-shift and the make-believe, and that in his heart of hearts he is chafing.

\section{II.}

A young poet inevitably begins by being a lover of poetry, and having fed his mind and his imagination on certain works which his taste pronounces to be immortal, he will set himself to compose masterpieces of his own. Certain lilts, certain rimes, certain phrases will have stuck in his subconscious mind, and will in the process of composition be thrown out as Jonah was by the whale. This, however, is not by any means the worst of the matter. It is a far more serious handicap to the novice, that the poets admired by him have taught him to use their eyes in looking at nature and humanity. They have taught him not only how to look, but also where to look. They 
have cast a glamour over certain subjects, causing their reader and fosterchild to pass by a multilude of others which he sometimes merely despises as nonpoetical, but oftener does not see at all. The result is known as derivative stuff, and the only thing that can enable an aspiring poet to shake off influences and produce work that matters is strength of character, which need not, and in the case of Wilfrid Gibson did not, become iconoclasm, though it often does, which indeed in a literary man bent upon realizing himself is pardonable enough.

Having written down this sentence I pause, reflecting that after all Gibson's strength of character may have led him too far, in that it has made him disown all his firstlings. He wants to be appreciated as the writer of Daily Bread, of Fires, of Borderlands, Battle, and Livelihood, not as Urlyn the Harper, nor as the author of The Nets of Love, The Golden Helm, and The Web of Life. And doubtless, for this attitude towards achievements which his heart cannot claim to be exclusively his there is much to be said. We know the story of the old gentleman who, listening to the sermon of an unoriginal parson, was heard to say at intervals, 'That was Blair', - 'That was Tillotson', - 'That was Stillingfleet', and so on. We can likewise imagine a reader versed in XIXth century poetry, perusing, with a due amount of pleasure, Gibson's earlier work, but interrupting his reading now and then to say, 'That was William Morris', - 'That was Tennyson', - 'That was Keats'. Sometimes the resemblance lies on the surface, as e.g. is 'King Hermaunce' ${ }^{1}$ ), a poem which might have come straight out of Morris's Defence of Guenevere volume. (Cp. e.g. The Sailing of the Sword). More frequently, however, the indebtedness in less glaring, though nobody could mistake the Tennysonian note here, in The Weary Singers:

There is no peace in all the wandering sea,

And keen the northern air with stinging life;

While we would rest; at least awhile, to be

Forgetful of the world from which we flee,

Wherein forever surges, without end,

The blind, unceasing strife.

Yea, we are weary of the whirl and din

Of storm-set days and fevered nights, that spin

Fresh sorrows ever for the morrow's dawn;

Weary of tossing heights and gulfs that yawn,

While o'er us, ever curving perilously,

White-foamed disasters bend.

('Uriyn the Harper', 56) ').

But again, in the same poem the spirit of John Keats, goaded on by jealousy, elbows Tennyson's ghost away from W. W. G. the medium :

So thick the soaring reeds, we may not see

The sea-green willows ranged along the shore,

Nor any hill beyond the vale, and we,

Escaped awhile from earth's immensity,

Dream as old gods within a little world

of peace, - where evermore

Fain would we lie, forgetting all that grieves,

Among the swaying calm of lily-leaves, -

3) King Hermaunce puts out to sea;

The sea is grey beneath the wind.

King Hermaunce of the Red City!

Mariners, mariners, where are your songs

when the wind is filling the blood-red sails?

(The Queen's Vigil, 1902).

7) Compare Tennyson's Ulysses and The Lotos Eaters. 
That thrust from glooming depths green spears in June, -

But now, through all the peace of summer's noon,

Spread like broad shields, when warriors endlessly

Slumber with banners furled.

May we not too forget who sang in vain?

May we not too forget, as they forgot

The singer and the clear, sky-soaring strain?

The labour and the toil and all the pain,

The darkened noon, the lightning cloven night

Of song remembered not?

Forget awhile the keen, consuming fire

That burned our souls to one white-flamed desire

Among the fierce red passions of the earth ?

Forget awhile the hunger and the dearth?

The gaunt and ghostly ever-wailing train

Of sorrows wan and white?

\section{III.}

Other influences might be pointed out, e.g. the Maeterlinckian trick of Ocreating an intolerable atmosphere of terror by making the same character Trepeat again and again, at intervals, the same shuddering exclamation ( $\mathrm{Cp}$. oThe Songs of Queen Averlaine in 'The Golden Helm'.) And yet, Gibson's tvery first volume contains work which, though undeniably in the tradition of English poetry, could have been written by no other poet. Let me quote Some specimens here:

Who is she that cometh with the wind about her blown,

Restless raiment gleaming full of colours of the sea,

Green as under-curve of wave, white as waters overthrown?

Wandering winds and waters tell me, who is she?

Deep in the dark of the forest I have builded a throne for my Dream :

And there in the noon of the night-tide, where light of the moon may not gleam

In shimmering raiment before me, throned, white, with a star on her brows

She sits, and I harp to the Vision in silence and night of green boughs.

Shall I gaze for a while in the pool Of the waters of rest,

Till the fulness thereof and the cool Have entered my breast;

Till the flame of my love and the fire That burns in my heart

Be quenched, and dream and desire Be shivered apart;

That my days may be filled as a cup With fresh flowing peace

From the heart of the earth welling up Till the life-light shall cease?

Nay, not for the peace of the earth That has been from the first,

Would I yield the keen passion of dearth, The rapture of thirst.

Surely this is poetry that lives, and yet it is disowned and, I understand, has been rigorously excluded from the Collected Edition published in 1917 
by the [American] Macmillan Company. I never saw the book, but 1 know from Professor Lyon Phelps's studies on contemporary English poetry (The Advance of English Poetry in the Twentieth Century, reviewed by me in this year's April issue of English Studies) that it opens with Akra the Slave (1904). Now I cannot help thinking that Gibson was ill-advised not only in rejecting much excellent work and including $A k r a$, but also in choosing this by no means imposing achievement to be like Abou Ben Adhem's name 'leading all the rest'. Its subject is that of Urlyn - unsympathetic king, sympathetic queen, and beauty-worshipping artist (whether harper, jester, or knightly troubadour) - a motif with which the mind of the youthful Gibson was continually obsessed and which has found its tersest treatment in King Ormel ${ }^{1}$, its best partly in Urlyn the Harper, partly in Queen Averlaine, but certainly its faultiest in Akra the Slave. Several of Gibson's earlier lyrics and narrative poems suffer from want of concentration, from linked sweetness too long drawn-out. The poet simply revels and wallows in descriptions for which the poetical theme merely provides the excuse, so that such a lyric as The Wanderer (very fitly, perhaps) seems to lead nowhere, and a story like The Torch - which ought to have been cast (or to be recast!) into ballad form ${ }^{2}$ ) - drags and flags. Akra suffers in like manner ${ }^{3}$ ) besides suffering, in places, from a too literary diction, which makes the poem unconvincing from a psychological point of view ${ }^{4}$ ) and at the same time clashes strangely with its irregular and unconventional rhythms. Any lover of poetry will prefer a ballad like The Unknown Knight (from 'The Golden Helm') or a lyric like The Parting of the Ways (from 'The Web of Life'), both disowned. Here is the first:

\footnotetext{
When purple gloomed the wintry ridge Against the sunset's windy flame,

From pine-browed hills, along the bridge, An unknown rider came.

I watched him idly from the tower, Though he nor looked nor raised his head;

I felt my life before him cower In dumb, foreboding dread.

I saw him to the portal win Unchallenged, and no lackey stirred

To take his bridle when within He strode without a word.
}

\footnotetext{
1) To be found in 'The Web of Life' and in my Golden Hours.

2) It would be interesting to compare The Torch with Ernst von Wildenbruch's well-known Hexenlied, in which a similar theme is treated in a far more direct and stirring way.

$\left.{ }^{3}\right)$ Compare the opening:

He thought to see me tremble

And totter as an oar-snapt reed,

When he spake death to me -

My courage, toppled in the dust,

Even as the head of cactus

The camel-keeper slashes

That his beasts may browse, unscathed,

The succulent, wounded green .....

4) Akra remembers a night in his early youth, before he was captured, when he lived in a cave with his kindred. The melted snow comes down the mountain-side in torrents and, couched within the cavern, the clamour keeps him wakeful. Afterwards in his sleep, it seems to surge about him, as the brawl of armed men. Then he springs from slumber and steals without to rouse the smouldering watchfire into flame and cast fresh crackling brushwood on the blaze, but he hears nothing save the choral noise of hill-waters singing to the stars etc. (My italics).
} 
Through all the house he passed unstayed, Until he reached my father's door;

The hinge shrieked out like one afraid; Then silence fell once more.

All night I hear the chafing ice Float, griding, down the swollen stream;

I lie fast-held in terror's vice, Nor dare to think or dream.

I only know the unknown knight Keeps vigil by my father's bed:

Oh, who shall wake to see the light

Flame all the east with red?

\section{And here is the second:}

Farewell! There is no other word to say

For us who leave so many words unsaid;

So many springs untasted by the way;

So many fruits ungathered; and who tread

Each kindling hour to ash beneath our feet;

Hungered, a-thirst - we dare not drink nor eat;

A-cold - the least, red flame of fire we dread.

Farewell! for here the valley-ways divide;

I cross the stream; the beaten track you keep;

Yet, both paths climb the barren mountain-side,

Though sundered by deep cleft and craggy steep;

And each, alone, must scale the perilous track,

Unfaltering, nor ever turning back

To look upon the valley, warm and deep -

The -summer valley of our lost delight :

Though fierce suns blind us; and, like driven spears

Thrust through the curved, steel-gleaming shield of night,

One after one, the frosty star-fires pierce

Our shuddering souls with terror; though the blast

Swoop on our clutching lives, and seek, at last,

To hurl us headlong down the chasm of fears.

Farewe11, farewe11! But yesterday we met -

Unknown, unknowing - yet from all time known.

Surely, our souls that do not rise or set,

Ere the sun kindled, or the stars were blown

To singing flame together roamed the night

Of chaos - ere God blinded space with light,

And took love in the toils of flesh and bone!

Farewell! The night falls on us; the sky lowers

With boding tempest; and on bitter breath

The north wind bears my cry, and shakes the towers

Of silence, till shrill echo answereth.

Already night divides our labouring feet;

Yet, in the peace of dawn, shall we not meet

Upon the white and silent peak of death?

\section{IV.}

Perhaps, in 'running down' Akra the Slave I have done the poet an injustice, for he may have revised $A k r a$ as he revised his six pastorals ${ }^{1}$ ) The Stonefolds, The Bridal, The Scar, Winter Dawn, The Ferry, and On the Threshold - before inserting them in the American Collected Edition. In the case of these six miniature plays, however, the revision seems to have amounted to little more -than a substitution of yous and yours for the thous

') First Ed. 1907 (The Samurai Press). The Ferry is also given in Golden Hours. 
and thees, thys and thines, which had been used throughout in the original version, and though we may be inclined to consider the revision an improvement, we must not forget that Gibson is a native of Hexham in Northumberland, and that the peasantry of the North Country still make an extensive use of thou etc. in their daily speech, so that nobody can charge the author of the first edition with any artificiality. His rustics are all of them rugged Northumbrians, shepherds chiefly, stern but decent and hardworking folk, with much native dignity of manner. "This is pastoral poetry of a new and refreshing kind - as unlike to the conventional shepherdshepherdess mincing, intolerable dialogue as could well be imagined," says Professor Phelps, an opinion which I am glad to endorse whole-heartedly; and, like him, I prefer The Bridal, 'perhaps the most impressive of them all', and quite free from the pathetic fallacy from which the title-piece, The Stonefolds, suffers, in which a baby and a lamb are born and die in the same stormy night.

Both Akra the Slave and the six 'Stonefolds' pastorals mark Gibson's transition-period, the romantic monologue by its manner, i.e. its irregular rimeless lines, the pastorals chiefly by their subject-matter, the dramatis personce speaking in regular blank verse, which has nothing Miltonic or Shakespearean about it but is the poet's own. Had Gibson until then entirely ignored the cottage, the dairy and the sheepfold, the humble roof in general? He had not. From the very first he had given his readers, in addition to his romantic minstrelsy, little genre-pictures of rural life, several of which can be put side by side with the Dutch poet Perk's most successful achievements. But these genre-pictures are French, and they are the work of a tourist, whose attention is drawn by a lonely shepherd (such as Millet loved to paint), or by a peasant-woman ${ }^{1}$ ) returning from market and just about to enter her cottage, - but the tourist does not strike up an acquaintance with the shepherd, nor does he enter the cottage at the same time with the peasant-woman to ask for some water and inquire about the children. The utmost thing his curiosity prompts him to do is to look in at a barn where corn is being threshed, the result being a beautiful little poem, The Thresher, in which after the first Rembrandtesque lines the poet communes with his own heart, but never thinks of voicing the inmost thoughts of the threshing hinds. There is still a long way for Gibson to go, and the road takes him back to his own people, first to the fells of Northumberland, and next to its shores, and next - his boldness increasing - into the monotonous tenements of manufacturing towns, and into workshops, and down into the grisly dark and the choking stife of the coal-pits.

We have arrived at the seventeen miniature plays collectively entitled 'Daily Bread' and published in 1910. There is nothing like them in the English literature preceding that date, and though the jerky, itregular lines and the austere diction of these dramatized 'emotional moments' in the lives

THE WIFE.

With laden basket homeward she returns,

Weary from market, with set, patient pace:

In the low sunlight glowing her calm face

Beneath her snow-white cap red-golden burns.

The yellow mud-walls under the brown thatch

At last she sees with kindling eyes a-shine:

With vague brief fears beneath the well-known vine

The day-long exile pauses, hand on latch.

('Urlyn the Harper', 43.) 
of working-folk have since found some imitators, most poets will be shy and continue to be shy of putting their artistic sincerity to such a crucial test. All exuberance, all adornment has been done away with deliberately. The 'Stonefolds' pastorals were far easier in conception and execution; the stuff afforded by rural life was far more plastic, far more malleable, and besides, there was always 'the wind on the heath, brother', as Jasper Petulengro ${ }^{1}$ ) would say, to make even toil appear less irksome, and glorious sunsets to give dreams of beauty. In 'Daily Bread' there is nothing but humanity at grips with hard and cruel and at the same time sordid circumstances. There is poverty and unemployment, making flowers look out of place. There is the fireman on duty, while his wife is dying in childbed. There is the stoker, scorched by his bursting furnace and brought home to die, the fisherman's wife waiting for her sons who have gone down in a storm; the mother who has to be operated on for cancer. - And there is fortitude, and helpfulness, courage, and general decency. Gibson, of Puritan stock, is not the man to wax sentimental over good-hearted wastrels. His poor are respectable poor, as the majority, of the working classes are in reality. They are not in want of 'conversion' in a Salvation Army fashion or on the lines of the disreputable hero of The Everlasting Mercy. Gibson has as successfully dispensed with the romanticism of wickedness as he has managed to do without swearwords, 'closhy puts', and 'bloody liars'.

In the Athenæum booklet 'Daily Bread' has been represented by three pieces, The Night Shift, The Operation, and Summer Dawn (a delightful thing this, which might be described as a dramatization of the well-known Dutch Hubert and Clare story, with the rich man left out), and I have little fault to find with the choice. But in my opinion the best piece far and away is The Garret, and as I have never yet seen this little drama, so bracing in its pure sincerity, singled out for any special praise, I am proud to single it out here and pronounce it a master-piece.

\section{V.}

'Daily Bread' has, until now, 'run' into four editions as the saying goes, though 'crawled' might be considered a more appropriate word here. In view of the many thousands of people who spend their shillings on inferior books and ephemeral stuff - leaving out of our account the hundreds of thousands who think it wicked waste to spend money on books at all the fact may cause a Heraclitus to shake his head and a Democritus to profess himself agreeably surprised ${ }^{2}$ ), - but it need not detain us. What matters in this connection is that, having found himself, having rid himself of poetic tags, and having learned to render the rocks of real existence in

1) Vide Borrow's novels.

2) In the approved Hegelian manner - though unconsciously so, I presume - the poet has humorously reconciled the two views in

THE PESSIMIST.

His body bulged with puppies - little eyes

Peeped out of every pocket, black and bright;

And with as innocent, round-eyed surprise

He watched the glittering traffic of the night.

"What this world's coming to I cannot tell,"

He muttered, as I passed him, with a whine -

"Things surely must be making slap for hell,

When no one wants these little dogs of mine."

(Friends,) page 25). 
their naked ruggedness, the poet could now permit himself to give - in his very own fashion - some sunshine (both as regards matter and treatment) beautifying the whole. The outcome is seen in 'Fires', a series of twentyone short stories in verse, several of which might, with far more aptness than Tennyson's Dora or Enoch Arden, be termed idylls. Indeed we may say that most of Gibson's 'Fires' are quite as perfect as that perfect Theocritean poem called The Fishermen. They are mellifluous without monotony, simple without baldness, poetical without purple patches, sincere and warmly human and withal very often full of strange glamour. And not a few of them are weird. It is remarkable that the weird ones - The Dancing Deal, The Old Man, The Crane etc. - received recognition from the first, whereas masterpieces like The Shop were for a long time objects of doubt and misgiving, - wise heads looking at each other wide-eyed, mutely wondering 'if such stuff could be poetry'.... Much to my satisfaction The Shop appears to have come into its own, as it has been included in the Athenæum selection, likewise The Machine; but what about The Slag, The Ovens, The Brothers and the rest? $\left.{ }^{1}\right)$ I regret I cannot convey any notion of their qualities; quotation is impossible, but then, were it possible to quote from these poems, which must be enjoyed and digested whole, it would be useless.

Next in publication is 'Borderlands', according to Prof. Phelps the least successful of the poet's works (with the inevitable exception of Akra). Now this is a verdict with which I find it impossible to agree, and so far from thinking the book more or less of a failure I maintain that it is in an important respect an advance on its predecessors. The book contains three dramatic dialogues, - not dramas, since in them it is not the play that is the thing, but the talk. They are, in Harold Monro's words ${ }^{2}$ ), “conversations about unusual matters, between people queerly and unsuitably brought together, who match their temperaments, try their qualities against each other, quibble suspiciously, describe egotistically, admit reluctantly or disparagingly or jestfully, and finally are caught or yield on a subtle point which has been skilfully suggested like a pervading theme through the course of the dialogue," and he goes on to say, quite justly, that "a peculiar intellectual excitement is maintained throughout the conversational vicissitudes of these pieces." I may add that these poems, whose general title is eminently apt, are respectively studies in romanticism, in anti-social feeling, and of 'the ideal versus reality', and they are democratic studies, in that, carrying on the work of Landor and Robert Browning, the point of view they adopt and develop is that of the lower orders. Personally I have been fascinated most, and that repeatedly, by number two, Bloodybusi Edge, in which a North Country poacher compares notes with a London crecksman who is in danger of the police. It has been objected to Gibson's work by Marguerite Wilkinson among others - that it shows little power of individualization, - and there is some truth in the objection as far a:s 'Daily Bread' is concerned, but surely the charge breaks down before Bloodybush Edge. Gibson's dialogue, too, has been found fault with by the American anthologist ${ }^{3}$ ), who seems to think it improbable that the characters in a dramatic episode should inevitably hit upon le mot juste. Does Miss Wilkinson then want an author, in his dialogue, to be a mere imitator of

') The Lighthouse seems to me the weakest of them; it suffers in places from the blemishes pointed out in Akra.

3) Poetry and Drama, Dec. 1914.

3) 'New Voices', 127. Why does not the lady object to the use of blank verse in dialogue? 
nature? What impossible, tedious and improfitable stuff such a process would yield! We want dialogue to be convincing, and the line separating what is convincing in dramatic art from what is unconvincing, is not merely a question whether such and such a word or sentence was really used or no. The boundary lies simply between that which a character might have said under the circumstances and that which he could never have said '). Here is a little fragment from Bloodybush Edge, and I think the dialogue will be found eminently convincing :

DICK (the Poacher). .... If you only stare

Hard at the darkest patch, for long enough,

You'll see that it's all alive with little stars;

And there isn't any dark at all.

TRAMP.

No dark!

If you'd been tumbling into those black holes,

You'ld not think overmuch of these same stars.

I couldn't see my hand before me. Stars!

Give me the lamps along the Old Kent Road;

And I'm content to leave the stars to you.

They're well enough; but hung a trifle high

For walking with clean boots. Now a lamp or so....

DICK. If it's so fine and brave, the O1d Kent Road,

How is it you came to leave it?

TRAMP.

I'd my reasons.

DICK. Reasons! Queer reasons surely to set you trapesing

Over Foulmire in the dark: though I could travel

The fells from here to Cheviot, blindfold. Ay!

And never come a cropper.

TRAMP.

'Twas my luck,

My lovely luck, and naught to do with reasons -

My gaudy luck, and the devilish dust and heat,

And hell's own thirst that drove me; and too snug

A bed among the heather. Oversleeping,

That's always played the mischief with me. Once

I slept till three in the morning, and ....

DICK.

Till three?

You're an early bird, if you call that oversleeping.

Folk hereabouts are mostly astir by three:

But, city folk, I thought ....

TRAMP.

I'm on the night-shift.

I sleep by day, for the most part, like a cat.

That's why though dog-tired now, I couldn't sleep

A wink though you paid me gold down.

DICK.

And what may your job be? Cat's night-shift, likely,

As well as day's sleep!

TRAMP.

Now, look here, Old Cock,

There's just one little thing that we could teach you

Down London way. Why, even babes in London

Know better than to ask too many questions.

You ask no questions, and you'll hear no lies,

Is the first lesson that's hammered into them.

No London gentleman asks questions. Lord!

If you went "What's your job?"-ing down our way,

You'ld soon be smelling someone's fist, I reckon;

Or tripping over somebody in the dark

Upon the stairs; and with a broken neck

Be left, still asking questions in your coffin,

Till the worms had satisfied you. Not that I

Have anything to hide, myself. I'm only

Advising you for your own good ....

1) Compare the impossible talk of the retainers in Browning's Blot in the Scutcheon. 
VI.

In 'Thoroughfares' there are three poems - Solway Ford, Wheels, and The Gorse - that lead from 'Fires' to 'Livelihood: Dramatic Reveries'; there are a number of others that are akin to the genre-pictures of Faring South in the 'Urlyn' volume; some studies of fear: lyrics that recall In the Forest (occurring in 'The Web of Life'); and a few more which show the poet in a new light. One of these last is The Wind, in which Gibson finds himself in the company of the Shropshire Lad:

To the lean, clean land, to the last cold height, You shall come with a whickering breath,

From the depths of despair or the depths of delight, Stript stark to the wind of death.

And whether you're sinless, or whether you've sinned It's useless to whimper and whine;

For the lean clean blade of the cut-throat wind Will slit your weasand and mine.

An other is The Vindictive Staircase;Or, The Reward of Industry. There is not a trace of humour in the poet's earliest volumes, the most plausible explanation being that he took himself too seriously and stood aloof from real life. Humour at any rate makes its appearance for the first time and not very daringly, in 'Daily Bread', especially in Summer Dawn. Once having gained admission it becomes a permanent guest (Compare The Snow in 'Fires', The Dreadnought and even The Gorse in 'Thoroughfares', several lyrics in 'Battle', 'Friends', 'Whin', and passages in 'Livelihood'), whilst in The Vindictive Staircase it blossoms into whimsicality. Some serious-minded people, among whom Professor Phelps, do not like it, more is the pity, and its metre being that of Browning's One Word More, it is considered sacrilegious.... But it has often made me, whose admiration and love for Browning are very great indeed, chortle in my joy....

In a doomed and empty house in Houndsditch,

All night long I lie awake and listen

While all night the ghost of Mrs. Murphy

Tiptoes up and down the wheezy staircase,

Sweeling ghostly grease of quaking candles.

Mrs. Murphy, timidest of spectres,

You who were the cheeriest of charers,

With the heart of innocence, and only

Torn between a zest for priests and porter,

Mrs. Murphy of the ample bosom,

Suckler of a score or so of children -

("Children? Bless you! Why, I've buried six, sir.")

Who in forty years wore out three husbands

And one everlasting, shameless bonnet,

Which I've little doubt was coffined with you -

Mrs. Murphy, wherefore do you wander,

Sweeling ghostly grease of quaking candles,

Up and down the stairs you scrubbed so sorely,

Scrubbed till they were naked, dank, and aching?

Now that you are dead, is this their vengeance?

Nobody, at any rate nobody with a notion of what war really means to an ordinary mortal compelled to carry arms and use them, has complained about the queer touches of humour in the uncompromising lyrics collected under the general title of 'Battle'. American critics have pronounced this book 
Gibson's most original contribution to literature, which is absurd and unfair, unfair to the poet himself and to others. The Bayonet is a remarkable piece of work, which keeps ringing in our ears and burns an indelible image on our brains ${ }^{1}$ ), but it can be matched from Sassoon's poems \%).

Sassoon, however, always writes from the point of view of a soldier, whether in action, neglected, disabled, or dead. Gibson includes noncombatants affected by the war as well, as in Salvage, in which the humour is as heart-rending as the unmitigated horror of The Bayonet:

\begin{abstract}
So suddenly her life
Had crashed about that grey old country wife,

Naked she stood, and gazed

Bewildered, while her home about her blazed.

New-widowed, and bereft

Of her five sons, she clung to what was left,

Still hugging all she'd got -

A toy gun and a copper coffee-pot.
\end{abstract}

\title{
VII.
}

This is not a note on which it would be well to end, and, fortunately, the poet has, since the publication of 'Battle', produced enough fine work - in 'Livelihood', 'Friends' and 'Whin' - to make this unnecessary. But I do not propose to survey these last volumes in detail; they will simply be drawn upon for a balance-sheet, which, final only as far as this study is $\times$ concerned, must in other respects be considered very provisional indeed.

Gibson has widened the scope of English poetry, introduced new forms, $\vec{\Rightarrow}$ improved upon and developed older ones, borne a hand in ridding the $\checkmark$ language of pseudo-poetic rubbish, at the same time enriching it by a discriminate use of colloquialisms, technical terms and North Country words. He has helped to increase the number of people who care for poetry, has interested readers to whom the bards of a bygone generation or the dandies 'I and aesthetes of the 'eighty-nineties' could mean nothing. He has interpreted the lives of the poor as Wordsworth, that splendid egoist, never did and never could, with a sympathy far beyond any that was at the disposal of D the recluse of Rydal Mount; in a form that Crabbe, who'alternately preached If at the poor and stood up as their advocate, but who never felt himself one of them, could not command; with a restraint and balance that John

This bloody steel Has killed a man.

I heard him squeal As on I ran.

He watched me come With wagging head.

I pressed it home, And he was dead.

Though clean and clear l've wiped the steel, I still can hear

That dying squeal.

2) There is this difference that, whereas Sassoon accuses explicitly, and apostrophizes 'purple majors' and 'yellow parliamentarians' as well as war and war-makers in general, Gibson's accusations are implicit, just as they were in 'Daily Bread' and 'Fires'. 
Masefield, real poet and warmly human man though he is, cannot emulate; with an occasional humour worthy of Thomas Hardy at his best, but mellower.... Here is an example from Whin:

\section{OLD MEG.}

There's never the taste of a cherry for me,

They're out of my reach on the bough,

And it's hard to be seeing them hang on the tree -

And no man to hand me them now.

It's hard to be travelling since Billy Boy died,

With the devil's own crick in my back,

With the gout in my knees and a stitch in my side -

And no man to carry my pack.

It's hard to be travelling the roads all alone,

When cherries hang handy and ripe -

And no man to find me a soft mossy stone,

And no man to kindle my pipe:

The debit side of the account? The poet is rather too fond of certain rimes, notably of fire and desire, to mention a minor blemish first. He is a conscientious artist, but not infrequently the artist is betrayed (by his facility) into using an 'artistic' (albeit unhackneyed) word instead of one that would be psychologically appropriate ${ }^{1}$ ). He has sometimes to plead guilty to sentimentalism and once or twice to banality (but is even the Shropshire Lad entirely free from these things?). Having broken new ground he wants the whole crop for himself to the last ear of corn or potato, leaving nothing for another to glean ${ }^{2}$ ). He has developed certain mannerisms which he should try to get rid of, especially one which we may call the Gibsonian trick of riding on a whiff of smoke, or a moving shadow, or a sunbeam, from the present into the past or the future. Even his goats are sometimes afflicted with this peculiarity, as e.g. Mabel in 'Thoroughfares' (page 16).

But I have come to the end of my cavilling and want to take the edge off my last remark by including a fine and effective specimen of this same Gibsonian trick. It is from Partners in 'Livelihood', where a merchant is described (from 'within') whose younger brother has absconded, leaving the business in a great mess. The sum total of the liabilities confronts him inexorably:

1) 'Whin' offers some examples. Here is one. The opening stanza of Unthank (page 16) opens:

The sheep are bleating in the rain

That drive across Lune Moor,

And he will never come again

At eve to Unthank door.

Now this opening is all right, with the only exception of the word eve, which I think is out of place where a peasant woman speaks. But worse follows:

Though I was naught to him, kind sleep

Comes rare and scant to me

Since he has left the bleating sheep

And gone across the sea.

'Naught' need not be objected to, being North Country English. But what about the epithet kind before sleep? It not only disturbs the rhythm, it dispels an illusion.

2) That his 'poetical instrument' lacks some 'strings', notably those of enthusiasm, indignation and lyrical rush, is another matter and one to which attaches no blame whatever. A lark trying to crow like a cock would merely make himself ridiculous. 
$10,711-$

Searing his eyeballs . .

Dappled his desk ...

When a ripple of light

And they were boys together,

Rambling the hills of home that April day,

Stumbling and plunging knee-deep through the heather

Towards Hally pike, the little lough that lay

Glancing and gleaming in the sun, to search

For eggs of inland-breeding gulls. He heard

The curlew piping; saw a blackcock perch

Upon a dyke hard-by - a lordly bird

With queer curled tail. And soon they reached the edge -

The quaggy edge of Hallypike. And then

The gulls rose at them screaming from the sedge

With flapping wings; and for a while like men

They stood their ground among the quaking moss,

Until half-blinded by the dazzling white

Of interweaving wings, and at a loss

Which way to turn, they only thought of flight

From those fierce cruel beaks and hungry eyes -

Yet stood transfixed, each on a quaking clump

With hands to ears to shut out those wild cries.

Then the gulls closed on Phil; and with a jump

And one shrill yell he'd plunged into the lake

Half-crazed with terror. Only just in time

He'd stumbled after through the quag a-quake

And caught him by the coat, and through black slime

Had dragged him into safety, far away

From the horror of white wings and beaks and eyes.

And he remembered now how Philip lay

Sobbing upon his bosom ....

Now those cries

Were threatening Phil again; and he was caught

Blind in a beating, baffling, yelling hell

Of wings and beaks and eyes. And there was naught

That he could do for him....

The poet is as yet only forty-two. He has broken new ground before, he has it in him to do so again. But as it is, his position in English Literature secure, even now.

Willem VAN DoorN.

\section{Epilogue.}

Limitations of space made it necessary that the above paper should stand over till December. Meanwhile 'Neighbours' has come from the press, both a bigger and a greater volume than its predecessor 'Whin'. Of its seven sections the first, which bears the same name as the short poems included under that title (nearly all of them dramatic or sub-dramatic) mark a new stage in the poet's progress towards a completer individualisation of his characters, combined, strange to say, with an enormous concentration of interest, a rigorous focussing of all our attention upon one intense situation. It is significant for the poet's method that all his characters bear names, even in pieces of only twelve lines, a simple device which, however, is not without its effect. Gibson's keen visualisation and his power of sensing and rendering emotion hardly admit of further development, but in some of the poems given in 'Neighbours' there is decidedly more rush than in former volumes, and in Jaunty Jack - Hollandice Jan de Branie - which I subjoin, there is a rush that simply takes our breath away .... . 
He'd run like a cat on the ridge of the roof,

And then to give proof

Of his daredevil wit he would stumble and slip

Down the slant of the slates and over the side

While agape we would fear for the end of his slide -

But just as he seemed to shoot over the edge

His fingers would grip

The lip of the gutter or maybe the ledge

Of a top-story window; and so he'd hang there

Cock-a-doodling and kicking his heels in the air.

And then he'd swing on to the ladder and pant

Up the slippery slant,

And take up his trowel and hawk of wet lime,

Going quietly on with the job he was at

With the same solemn face and sly rake of the hat

As though he had worked without stopping to wink

The whole of the time,

So sober and smug that a newcomer 'd think

That never a notion at all he had got

That wasn't concerned with the new chimneypot.

And no one could guess he was wedded for life

To a slut of a wife,

And had five gaping lasses and five gaping boys

To feed and to clothe and to keep in shoe-leather,

And to scrub every Saturday night all together

At the scullery tap with a splash-dash and squall

And the hell of a noise.

Then one dark winter morning his pride had a fall -

Tripped over his shadow, and headlong down stairs,

And ended his jests and his lardy-da airs.

Several of the poems in the other sections might be described as journalism raised to the dignity of poetry. How we should like to have pieces by Milton or Dryden illustrating contemporary events as forcibly and successfully as Bacchanal, celebrating November $1918 \ldots \ldots$

Into the twilight of Trafalgar Square

They pour from every quarter, banging drums

And tootling penny trumpets: to a blare

Of tin mouth-organs, while a sailor strums

A solitary banjo, lads and girls

Locked in embraces in a wild disheve1

Of flags and streaming hair ....

Last of all there is a section named 'Salvage' giving five poems rescued, very deservedly, from 'a discarded volume published in 1905', viz. from 'The Nets of Love'. They have undergone some revision, not much, where only some was needed, and I could wish the poet would do the same thing with some other discarded volumes. With The Arrow (given on page 166) it would be interesting to compare Yeats's Song of Wandering Aengus, which preceded it by a few years in order of composition, but which I do not think was known to Gibson at the time.

In the 'Neighbours' volume the Gibsonian trick already referred to is still much in evidence, partly as a result of the poet's striving to render 'emotional moments' with a maximum of poignancy. I think the trick, having done its due amount of useful work, should now be given up. Could not Gibson, the North Countryman, oblige at least one sincere admirer of his with more stories, ballads by preference?

W. v. D. 


\section{Bibliography.}

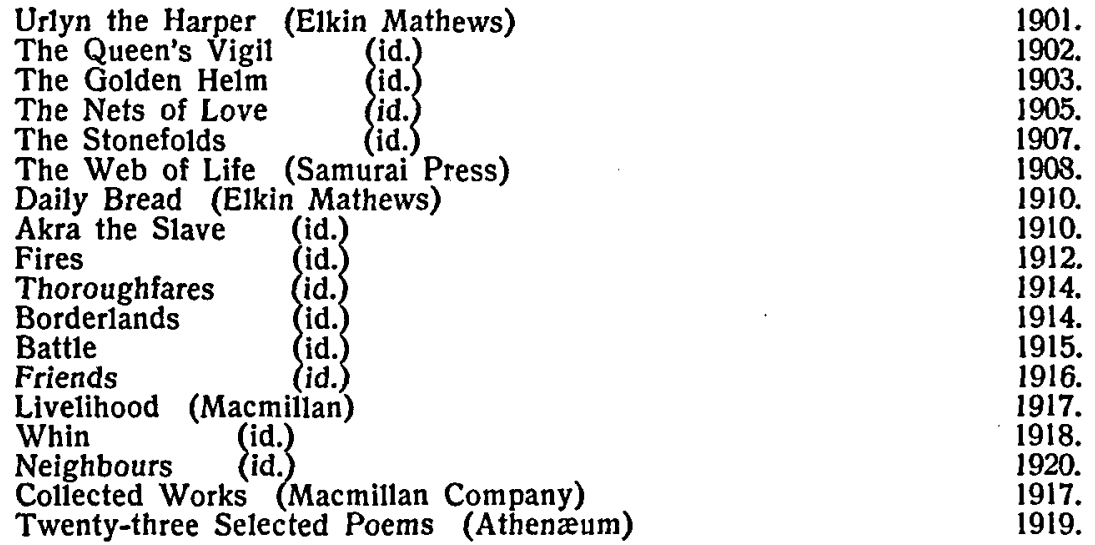

\section{Notes and News.}

English Association in Holland. The first series of Association lectures for 1920/21 was held between November 24-29. Mr. John Drinkwater -lectured before the local branches at Groningen, Haarlem, the Hague and Rotterdam on Poetry and the Drama: the Relation of Art to Life.

$\cong$ As the present issue of English Studies had to be struck off before these dates, it was impossible to insert a report, which will be held over till the next number.

The second series of lectures will take place between January 24th and ¿30th when Mr. Walter de la Mare will read before all the local branches, also including those at Amsterdam and Utrecht, on various literary subjects. Members will, as usual, be notified of the dates and places by their branch zsecretaries, while the lectures will also be announced in the local press.

In consequence of an arrangement between the Association Committee and Uthe Society Nederland-Engeland, members of the Hague and Amsterdam branches obtained free admittance to the lectures of Mr. Yussuf Ali, organised by the Society during the month of November. The Society has declared its readiness to co-operate with the English Association whenever possible.

The address of the Association Secretary is Miss J. M. Kraft, 5 Leidscheweg, Utrecht.

Modern Humanities Research Association. This Association was founded at Cambridge on June 1st, 1918. Its main object is the encouragement of advanced study in Modern Languages and Literatures by co-operation, through correspondence, personal intercourse, the interchange of information and counsel, and financial support for students engaged in research. The Association aims at improving and facilitating means and methods, and seeks such co-ordination of isolated effort that those interested or engaged in the same branch of research shall be kept informed of each other's work, and that unnecessary duplication of energy shall be avoided. 